\title{
G. H. Mead's Philosophical Hermeneutics of the Present
}

Scott C. Taylor

\section{OpenEdition}

1 Journals

\section{Electronic version}

URL: http://journals.openedition.org/ejpap/1694

DOI: 10.4000/ejpap.1694

ISSN: 2036-4091

\section{Publisher}

Associazione Pragma

\section{Electronic reference}

Scott C. Taylor, « G. H. Mead's Philosophical Hermeneutics of the Present », European Journal of Pragmatism and American Philosophy [Online], XI-2 | 2019, Online since 24 December 2019, connection on 16 June 2020. URL : http://journals.openedition.org/ejpap/1694 ; DOI : https://doi.org/10.4000/ ejpap.1694

This text was automatically generated on 16 June 2020 .

\section{c) (i) $९$}

Author retains copyright and grants the European Journal of Pragmatism and American Philosophy right of first publication with the work simultaneously licensed under a Creative Commons AttributionNonCommercial-NoDerivatives 4.0 International License. 


\title{
G. H. Mead's Philosophical Hermeneutics of the Present
}

\author{
Scott C. Taylor
}

\section{Introduction}

1 George Herbert Mead spent the last years of his life reflecting on a pragmatic account of temporality and emergence. In his notebooks, later to be published in The Philosophy of the Act, Mead poses the question, "Does the significance of the results of historical investigation and consequent reconstruction belong to the past where events lie, or is it to be found in the present or future?" (Mead 1972: 92). He quickly answers, without much defense, "the significant content that historical research reveals" is "a newly discovered present which can only be known and interpreted in the past which it involves." It is within the pages of Mead's The Philosophy of the Present, "The Nature of the Past," and select fragments in his The Philosophy of the Act that a compelling hermeneutic account of past, present, and future is developed.

2 In what follows I draw together what is a largely neglected account of the hermeneutic thrust of Mead's late writings. In particular, I argue that Mead's philosophy of the present also amounts to a theory of interpretation. In an open dialogue with a number of Hans-Georg Gadamer's most fundamental concepts for his philosophical hermeneutics, I demonstrate how Mead's notion of emergence in the present of both past and future neatly aligns with Gadamer's notions of tradition, prejudice, and application (phronesis), as required for a hermeneutic understanding of what Gadamer calls "the life-powers of the present." I will trace the foundation of this common ground by highlighting the pivotal influence of Wilhelm Dilthey on both Gadamer and the young Mead. Then, I will draw out the consequences this mutual influence has on the critique of the methodological historicist tradition. Throughout I demonstrate several missed opportunities by Hans Joas at providing a philosophical hermeneutic account of Mead's work. It is my intention to display how together the traditions of philosophical hermeneutics and pragmatism inform one another. 


\section{The Influence of Dilthey on Mead's Philosophical Hermeneutics of the Present}

3 What is largely accepted as the book that re-introduced Mead to European social thought, Hans Joas' (1997) G.H. Mead: A Contemporary Re-examination of his Thought makes no mention of the affinities between the works of Mead and Gadamer. In the same text, we are reminded, however, of Dilthey's influence on the young Mead (Joas 1997: 4, 18-9; see also Jung 1995). From April 1889 to October 1891, Mead was registered in the philosophy department at the University of Berlin (Joas 1997: 218). ${ }^{1}$ While there, he enrolled in Dilthey's Ethics and History of Philosophy courses, and undertook to write a dissertation under Dilthey, the topic of which was a critique of empiricism's concept of space (Joas 1997: 19, 218). Unfortunately, he was never to write this dissertation, though his Carus lectures may be understood as an argument against a theory of spacetime that does not acknowledge novelty, or the emergent, and as such is a return to his youthful preoccupation with the ideas that were stimulated during his time under the study of Dilthey. For Joas (ibid:: 18), "this fact" of Dilthey's influence "is of essential importance for an understanding of Mead's roots." Now, it is important to note that this period of study under Dilthey occurred during the same years that hermeneutics displaced psychology as the focal point of Dilthey's thought (Bollnow 1936; see also Grondin 1994: 88). However, nowhere in his book on Mead does Joas provide any discussion of Mead's work in relation to Dilthey's hermeneutics. Instead, Joas focuses on the psychological similarities and differences between the two thinkers. The "crucial difference" of course is whereas Mead recognized the self as a set of complex social structures, Dilthey remained committed to developing a methodology that reveals the unshakable foundation of the self in order to emancipate the human sciences from the natural sciences (Joas 1997: 42). Interestingly enough, as will soon be shown, this is the same critique that Gadamer also gives of Dilthey.

\section{Interpreting the Emerging Present in Mead and Gadamer}

Mead's The Philosophy of the Present is no doubt a hurried text. Written for the American Philosophical Association's annual Carus lectures in 1930, his work was largely completed during his travels from Chicago to Berkeley, California (Joas 1997: 167; Mead 2002: 7). Mead died a year after the completion of this manuscript, and illness brought a publishable redrafting of his lectures to a halt (ibid.: 7). Nonetheless, Mead's lectures were published posthumously under the same title, with an editorial inclusion of supplemental essays. Similarly, Gadamer's fifth edition of the original German Truth and Method includes supplemental essays. Indeed, we know Gadamer insisted on including these supplemental texts as part of the whole of his Truth and Method (Grondin 2003: 13). It is worth noting in passing that the very idea of acknowledging the need to bring to light the supplemental aspect conditional to all present understanding serves as an analogy for Mead's theory of the present. From this viewpoint, we may also frame the students' notes and Charles Morris's editorial liberties in Mind, Self, and Society as necessary supplements to the reading of Mead. 
5 Possibly the most important of Gadamer's supplemental essays is his "Hermeneutics and Historicism." Towards the end of this essay, Gadamer makes a set of interrelated claims on philosophical hermeneutics, historicism, and temporality from which the discussions that follow will pivot. Gadamer states that the historicist who takes himself too seriously will in time become un-historical, for that image of the historicist returns to "the ideal of complete enlightenment" (Gadamer 2006: 530-1). It is this ideal that gives way to, as Gadamer puts it, the "historical irrationalism of Dilthey" (ibid.: 531). He goes on to say:

Is it not the utopian ideal of a present in the light of which the whole of the past will, as it were, be entirely revealed? Historical thinking does not at all seem best characterized as applying the superior perspective of the present to the whole of the past; that is rather the obstinate positivity of "naive" historicism. Historical thinking has its dignity and its value as truth in the acknowledgment that there is no such thing as "the present," but rather constantly changing horizons of the future and past. It is by no means settled (and can never be settled) that any particular perspective in which traditionary thoughts present themselves is the right one. "Historical" understanding, whether today's or tomorrow's, has no special privilege. It is itself embraced by the changing horizons and moved with them. (Ibid.)

6 I take this to mean what Gadamer has called elsewhere in passing "the life-powers of the present" (Gadamer 2008: 6). Now, it is important to note, again, Gadamer's parenthesizing "the present" in the above quote. It is not that there is no such thing as the present, but that there is no "complete enlightenment" of the present. Accordingly, he notes in his 1981 essay "The Old and The New," "The openness to what is new, the life in expectation is our constant present" (Gadamer 2019: 53). Thus, there is no special privileged perspective that allows for a present that is "entirely revealed."

7 For those who are familiar with Mead's philosophy of temporality, Gadamer's words strike a glaring resemblance to the consequences of Mead's assertion that "reality exists in the present" (Mead 2002: 35; see also Mead 1964: 345-54). This present is not to be understood from the abstracted "knife-edge present" of the natural sciences, a present devoid of change and passage, but as a specious present (Mead 1972: 220-1; see also Miller 1973: 172-87). As such, whatever we experience, we experience in its temporal spread. And within each temporal spread there is a "tang of novelty" (Mead 1964: 3). ${ }^{2}$ Mead (2002) attests it is to the determinant of the natural sciences that they view the instant in time as capable of being wholly revealed. Much is lost in human understanding when their philosophies of the present do not permit for the emergence of novelty within the human experiencing of the present, for the experiencing of the present is always an "integration of what is taking place" (ibid.: 51). That is to say, what makes for continuity and novelty is the continual process of adjustment in the present, where the past conditions the novel event, which at the same time enlists a reinterpretation of our past experiences and future expectations. ${ }^{3}$ The emergent event is a surprise, a break, a discontinuity (Mead 1964: 347). Continuity is the immediate resolution of the surprise or break (ibid.: 345-54).

Emphasizing the temporal nature of our existence, for Mead, the specious present is also to be understood as an act (Mead 1972: 65; see also Rosenthal 2000: 126-7). "We actually see a bird fly, but we do not see it as one of Zeno's points or at a fixed location in space, then at another, then at still another, and then add these positions together to get motion or change of position." (Miller 1973: 172; see also Mead 1972: 65). We never experience in instants, rather the unity of experience is the act (Mead 1972). The 
present entails both a before and an after. However partial, recent memory and immediate anticipation are within its limits.

9 For Mead, to understand time is to understand the emerging event or novelty within experience and how novelty can be adjusted to reflect a familiarity with our past, present, and future plans. As Rosenthal notes, "the process of adjustment between the old and new is constitutive of the passing present" (Rosenthal 2000: 126). We may then say that the past and future serve as integrative functions for the present. To put it in idiomatic form, the past and future help us get our bearings: "The bird abruptly left the tree and is soaring in a direction opposite from me. I do not have to duck." To put it figuratively, the present is not each page of a flipbook, it is the whole flipbook in motion. The past merges with the present in the same temporal space that the future emerges. This is why Mead states that "the past is an overflow of the present" (Mead 1964: 348). The past doesn't have to be the case, but it is always cased in the present.

Acknowledging the "tang of novelty" in each present experience, then, would pose serious questions to common notions of causality in the natural sciences. Instead, it would demand that each novel experience in our present reconstruct the nature of our past and our conduct-oriented predictions of the future.

11 In his 1964 essay "Is There Causality in History?," Gadamer makes a distinction between causal and historical experience. What distinguishes history from natural science is that in the natural sciences each cause has a fundamental knowable and equal effect whereas for history, "small causes have huge consequences" (Gadamer 2019: 4). These consequences in history are, however, not by necessity foreseeable (ibid.: 5). Gadamer states: "It obviously belongs to the experience of those who stand within history that it surprises them." (Ibid.). We are open to the surprising - let us say, novel - event when we orient ourselves to the world historically. Through a surprising event we are met with a discontinuity between cause and effect. What's more, as soon as we question causality, Gadamer tells us, we are posing a practical problem (ibid.: 3). The result is the following: "[Individuals] try to come to grips with the situation in which they find themselves and find the right course of action, do what is required and handle the situation in the desired sense." (Ibid.: 4). "Understanding, then, is a special case of applying something universal to a particular situation." (Gadamer 2006: 310). Still, Gadamer (2019: 4) formally divides the causal and the historical into two separate dimensions of study. Unlike Gadamer, Mead explicitly collapses the causal and historical experience in his notion of the specious present. There universal and particular, continuity and novelty, causality and surprise, reflection and action are intimately intertwined. Nonetheless, for both thinkers, historical experiencing involves direction or purpose as much as it involves a repurposing of the past. It is important to highlight, however, that both Mead and Gadamer recognize purposefulness as a primary feature of any explanation of causality, and both acknowledge Aristotle's causes as the origin of this notion (Gadamer 2019: 7-9, 12; Mead 1972: 641). Insofar as the teleology of causality is expressed as the successful restoration of continuity in a novel present in order to appropriate future conduct, by applying Mead's specious present to Gadamer's critique of historicism, we then dissolve Gadamer's "schism" of causality's continuity and history's novelty (Gadamer 2019:5).

When rethinking causality from an historically-effected consciousness, then, the inevitability of cause and effect allows for continuity and novelty, for "the character of the past is that it connects what is unconnected in the merging of one present into 
another" (Mead 1964: 351). In other words, when we say "inevitability" in reference to causation what we are really saying is "the continuity in the passage of events" (ibid.: 350). Thus, inevitability is as much a successful readjustment to the present as it is a determinate of the past. It is important to remember that "without this break within continuity, continuity would be inexperienceable," that is, the novelty of surprise is necessary for an experiencing of continuity and deliberative action (ibid.). The past serves as an integrative function. As such, a constant restructuring of our immediate experiencing is the natural response to a present that can never be "entirely revealed." Here, Mead's notion of the specious present advances Gadamer's rebuke of Dilthey's "naïve historicism."

In "the age of unconditional faith in science" (Gadamer 2019: 6) the knife-edge present prevails where the belief in a wholly revealed in-itself present-as-an-instant is achievable. Mead's specious present, much like Gadamer's hermeneutical experience, demands a historically-effected response to the present that is open to emergence, novelty, and reconstruction. When Gadamer speaks of "no such thing as 'a present"' it appears that he is trying to articulate something like the "knife-edge present" which Mead is also criticizing. Had Gadamer conceptualized his argument against historicism as a critique against any historical investigation that "implies that there is or has been a past which is independent of all presents" (Mead 2002: 40), ${ }^{5}$ which is also another way of criticizing temporality as a series of isolated instants, his view would allow for an explicit distinction between an open (specious) present versus a closed (instant) present. Instead, Gadamer leaves himself open to the misinterpretation that there is no method whatsoever from which to arrive at a more accurate understanding of the present. For Gadamer states in the Afterword to his Truth and Method:

It was, of course, a flat misunderstanding when people accused the expression “ truth and method" of failing to recognize the methodical rigor of modern science. What hermeneutics legitimates is something completely different, and it stands in no tension whatever with the strictest ethos of science. No productive scientist can really doubt that methodical purity is indispensable in science; but what constitutes the essence of research is much less merely applying the usual methods than discovering new ones - and underlying that, the creative imagination of the scientist. (Gadamer 2006: 555)

Mead makes the same point when he states that, "while the conception of an 'in-itself' irrevocable past is perhaps the common background of thinking, it is interesting [...] that the research scientist looks forward not only with equanimity but also with excited interest to the fundamental changes which later research will bring into the most exact determinations which we can make today." When Mead (2002: 41) goes on to say that "[t]he picture which this offers is that of presents sliding into each other, each with a past which is referable to itself, each past taking up into itself those back of it, and in some degree reconstructing them from its own standpoint" we notice a conceptual resemblance to Gadamer's picture of a fusion of horizons, where "the horizon of the present cannot be formed without the past" (Gadamer 2006: 305). Nearly identical in tone and content to Mead, Gadamer continues: "There is no more an isolated horizon of the present in itself than there are historical horizons which have to be acquired. Rather, understanding is always the fusion of these horizons supposedly existing by themselves." (Gadamer 2006: 305; his emphasis). Unbeknownst to him, Natanson (1953: 772) captures the link between the two nicely when he states that "the content and meaning of the past event are, for Mead, structured and continually restructured in terms of a present that is itself within a horizon of temporal movement." What's 
more, Mead scholar Tonness (1932: 604-5) refers to this "extension of horizons" of the present situation as exhibiting a "field of orientation." ${ }^{6}$ In this sense, Gadamer's view of horizons captures the same contextualizing experience of the interpreted present as does Mead's specious present.

When Miller (1943: 44-6) reflects on what starts the scientist thinking for Mead, his interpretation leads him to discuss such notions as "prejudice," "hypothesis," and even "tradition." Yet it is not only Natanson (1953), Tonness (1932) or Miller (1943) whose discourse on Mead shares in character that of Gadamer. In a fragment in his The Philosophy of the Act Mead emphasizes the knowing of the past and causal future within the present as a hermeneutical task. ${ }^{7}$ As it is an often-ignored passage, it is worth quoting Mead at length here. He states:

The passing present, compounded of the past which is determined by the interpretation of the present and the future which comes to us as alternative possibilities, is what we have. The past is always necessary, but the past which is there is not necessary, i.e. is dependent upon the future which determines the present and its interpretation. It is the emergent that determine the selection of the futures and, hence, the pasts that are their so-called causes. The values are absolutes that arrive. The pasts that succeed one another could never be prophesied from one another. Nothing is lost, but that which arrives that is novel gives a continually new past. Its reality is in its interpretation of the present. (Mead, 1972: 616; emphasis added)

In what follows, I will focus on how Mead's understanding of how the emergent in experience (that is, the event that brings forth the present), to use a Gadamerian, phrase "speaks to us." To shift toward this direction, I will note first the affinity in language between these two thinkers themselves.

\section{Interpreting the Present as Understanding the Emerging Event}

Before settling on the more evocative title of Truth and Method, Gadamer played with the idea of calling his manuscript Understanding and Event (Grondin 2003: 13). In light of this, a comparison to Mead's The Philosophy of the Present may advance a clearer comparison, as Mead often uses the words present, emergent, happening, novelty, and event interchangeably (Mead 1964; 2002). How does one come to understand an event? And what comes along with us when we interpret such an event? Both Mead and Gadamer were searching for answers to the same questions. For Gadamer, understanding is both interpretation of and participation in the event of tradition, "a process of transmission in which past and present are constantly mediated" (Gadamer 2006: 290-1). As an interpretation, understanding is both a statement and a question (Gadamer 2007: 242). As a participating, it is inherently practically oriented. It is an application (Gadamer 2006: 305-20). As Hoy aptly puts it, Gadamer's emphasis on interpretation as application is a "philosophical point about the interest-bound character of all knowledge" (Hoy 1982: 111). Interpretations always serve a purpose. For Mead, the locus of reality is the present. And since each present is a socially mediated event, each present participates in the sociality of traditions (Mead 2002). Mead defines an "emergent event" as "the occurrence of something which is more than the processes that have led up to it and which by its change, continuance, or disappearance, adds to later passages a content they would not otherwise have 
possessed" (Mead 2002: 52). That is to say an emergent event leaves a novel trace from the past and marks our future conduct.

Gadamer makes a similar claim when he states, "[T]here can be no doubt that the great horizon of the past, out of which our culture and our present live, influences us in everything we want, hope for, or fear in the future. History is only present to us in light of our futurity" (Gadamer 2008: 8-9). Thus, understanding gives new direction as much as it restructures the experience of the past, for " $[t]$ he openness of the future is the clarity of our existence itself" (Gadamer 2019: 53).

For Gadamer as for Mead we apply a reframing of the past as it meets the present experience in order that we can achieve a future task (Gadamer 2006: 291; Mead 2002: 57). So, when Gadamer says that all statements are an answer to a question he is implying that each interpretative statement is future-oriented, that is, a task, for "it responds to a challenge" (Gadamer 2007: 242). Gadamer explicitly acknowledges this in a later article where he gives a historical account of the notions of subjectivity and intersubjectivity (Gadamer 2000: 280-1). Gadamer does so by highlighting a Heideggerian inspired notion of "givenness-on-the-way," where Dasein as thrown begins its present with prejudice to a non-given future. From this perspective, nothing is given. We are thrown into the task of understanding. This is what Gadamer means when he says that historically-effected consciousness is more Being than consciousness (as quoted in Warnke 1987: 80). He says,

Long before we understand ourselves through the process of self-examination, we understand ourselves in a self-evident way in the family, society, and state in which we live. The focus of subjectivity is a distorting mirror. The self-awareness of the individual is only a flickering in the closed circuits of historical life. That is why the prejudices of the individual, far more than his judgments, constitute the historical reality of his being. (Gadamer 2006: 278)

Being thrown, a historically-effected consciousness admits that it begins to understand from a prejudiced position, and as such, "to see that any understanding of a subjectmatter is necessarily prejudiced [...] is to see that the idea of reason itself refers to that which has come to be taken as rational within a particular tradition" (Warnke 1987: 80, emphasis added; see also Bernstein 1983: 130). As a result, it is our situatedness within a tradition that our historical understanding limits the arbitrariness of our particular perspective and reinforces a whole "history of interpretations" of the emergent present (Warnke 1987: 80). To note, this notion is closely related to what Mead (2002) means when he describes emergence as a social present. "The general structure of understanding," Gadamer reminds us, "is concretized in historical understanding, in that the concrete bonds of custom and tradition and the corresponding possibilities of one's own future become effective in understanding itself' (Gadamer 2006: 254). Both Mead and Gadamer recognize that any historical method that attempts to ground the past once and for all, as a "real past," slides into a theological or metaphysical given. This is both Mead and Gadamer's issue with Dilthey's tenacious attempt to ground the human sciences in a particular method. For Gadamer as much as Mead, then, our understanding of our present emerges out of our lived past, both in our individual prejudices and communal traditions, and our future oriented-ness. The past is given reality only insofar as it provides our present with a task.

21 Now, since understanding is a participating in an event of tradition, and as such, it is "a process of transmission in which past and present are constantly mediated," Gadamer is forced to admit that it is incumbent upon hermeneutic theory to "validate" the ways 
in which past and present are constantly mediated (Gadamer 2006: 291, 295). Mediation suggests an intervention in which to reconcile or resolve a dispute. Here, the dispute is between our previous beliefs of the past with the emergence of an event. As we know, events always occur in the present. It is the job of the hermeneutic, then, to validate how tradition participates in the present. That is, philosophical hermeneutics must in time give reasons for the understanding of a text, object, behavior, communication, etc. that is landed upon. What Gadamer neglects, however, is a clear argument for how an event in the present can share in novelty and continuity with the past. In this regard, while remembering Mead's critique of the natural science's philosophies of the present, Gadamer can be said to have fell for the same pitfalls the natural sciences arrive upon when attempting to articulate the reality of emergence or novelty.

In Beyond Objectivism and Relativism: Science, Hermeneutics, and Praxis, Bernstein calls attention to how Gadamer's hermeneutical understanding, conditioned by the temporality of prejudices and prejudgments, creates a threefold character. Bernstein states: "[prejudices and prejudgments] are handed down to us through tradition; they are constitutive of what we are now (and are in the process of becoming); and they are anticipatory - always open to future testing and transformation" (Bernstein 1983: 140-1). Though Bernstein does not bring up Mead or any of the pragmatists in this regard, it was his intent to implicitly link the practical import that founds science and hermeneutics (Bernstein 2010: 29). Mead perfectly sums up Bernstein's point about the threefold character of Gadamer's hermeneutical understanding when he remarks that "[t]he passing present, compounded of the past which is determined by the interpretation of the present and the future which comes to us as alternative possibilities, is what we have. The past is always necessary, but the past which is there is not necessary, i.e., is dependent upon the future which determines the present and its interpretation." (Mead 1972: 616). When Mead describes the passing present as "what we have" he is reminding us, much like Gadamer had, that there is no "special privileged" "perspective in which traditionary thoughts present themselves [as] the right one." We begin with "what we have" in the present. ${ }^{8}$ And it is for this reason that Mead states that "[p]asts that we are involved in are both irrevocable and revocable" (Mead 2002: 36). Thus, the irrevocability of the present can be understood as necessary prejudice, though our prejudices are never incorrigible. To highlight the affinity between these two thinkers, then, we must heed Gadamer's plea to "fundamentally rehabilitate the concept of prejudice" by acknowledging those notions where Mead effectively articulates, though not directly in name, both a notion of prejudice and its practical import in temporal understanding (Gadamer 2006: 278).

\section{Prejudice as Hypothesis: Integrating Gadamer and Mead's Philosophy of the Emergent Present}

Gadamer's (2006: 273) claim that "the fundamental prejudice of the Enlightenment is the prejudice against prejudice itself" is not a call for accepting the authority of prejudice and tradition uncritically. ${ }^{9}$ It is also not an affirmation of prejudice as understood to the modern ear. Rather, his discourse on prejudice is a genealogy of the origins of the use of prejudice in understanding. And it is in this genealogy that we come to find the modern conception of prejudice, as it began in the Enlightenment, as a distorted view of the notion. The Enlightenment critique of religion forged a complete 
disavowal of any judgment that does not have a methodological justification (Gadamer 2006: 273). In the wake of this critique, the distorted negative view of prejudice remains to this day. It is worth quoting Gadamer at length on the matter:

Actually, "prejudice" means a judgment that is rendered before all the elements that determine a situation have been fully examined. In German legal terminology a "prejudice" is a provisional legal verdict before the final verdict is reached. For someone involved in a legal dispute, this kind of judgment against him affects his chances adversely. Accordingly, the French préjudice, as well as the Latin praejudicium, means simply "adverse effect," "disadvantage," "harm." But this negative sense is only derivative. The negative consequence depends precisely on the positive validity, the value of the provisional decision as a prejudgment, like that of any precedent. Thus "prejudice" certainly does not necessarily mean a false judgment, but part of the idea is that it can have either a positive or a negative value. This is clearly due to the influence of the Latin praejudicium. There are such things as préjudgés légitimes. This seems a long way from our current use of the word. (Gadamer 2006: 273)

After excavating the original conception of prejudice, its original usage begins to approximate the same linguistic function as a hypothesis. Much like a hypothesis, a prejudice is a "judgment that is rendered before all the elements that determine a situation have been fully examined." It is as "provisional" as a hypothesis. In what follows, I will argue for the practical comparability between the everyday original notion of prejudice with the formal - dare I say, methodological - notion of hypothesis in scientific discovery. ${ }^{10}$ By doing so, the similarities between Gadamer and Mead's philosophies of the present and emergence will come to light.

To begin, when Mead (1972: 67) refers to a hypothesis as necessarily situated in the biographies of individuals, he is essentially recognizing the initial stage of inquiry as intimately tied up with an individual's historicity. ${ }^{11}$ In a later comment regarding the interrelatedness between individual, community, and historicity, Mead is compelled to speak of prejudices. He states:

History serves a community in the same way as the memory does the individual. A person has to bring up a certain portion of the past to determine what his present is, and in the same way the community wants to bring up the past so it can state the present situation and bring out what the actual issues themselves are. I think that is what history uniformly is. It is always prejudiced in one sense, that is, determined by the problem before the community. (Ibid.: 80-1)

Mead also refers to hypotheses as "the very stuff of our knowing" (Mead 1972: 63). This "stuff" of our knowing is the unquestioned "world that is there" (Mead 1972; see also Miller 88-103). This world that is there is an undifferentiated world that is not doubted but is not indubitable (Lee 1963). In brief, Mead and Gadamer want to do justice to our human finitude by acknowledging the irreducibly prejudiced historicity of our present situatedness. To ignore our prejudices as if they do not exist, blocks the road of inquiry in the same way it distorts our human reality (Gadamer 2006: 278).

As with hypotheses, "[t]he prejudices and fore-meanings that occupy the interpreter's consciousness are not at his free disposal. He cannot separate in advance the productive prejudices that enable understanding from the prejudices that hinder it and lead to misunderstanding" (Gadamer 2006: 295). Rather, as Mead notes, an individual's "foresight does not go beyond the testing of his hypothesis" (Mead 1964: 3). Our prejudices, just as our hypotheses, are those contents of a problematic situation that are "immediately functional" (Mead 1972: 219). They initiate an act. They are our initial 
hypothetical-prejudicial response. Prejudices "constitute the initial directedness of our whole ability to experience" (Gadamer 2008; my emphasis). Hermeneutics, much like the initial stage of Mead's experimental method of both the sciences and individual conduct, begins with a prejudiced "what is there" that is always articulated as a hypothesis to a present problem. Where for Gadamer (2007: 242) all statements are questions, for Mead (1972: 88-9), all propositions are hypothetical questions, and as such, statements and propositions "can become a problem." If all propositions are hypothetical, all propositions begin with a prejudice that demands testing. Before all else, then, is the problem of interpretation. This is precisely what Gadamer means by the universality of the hermeneutic problem (Gadamer 2008: 3-17).

It is important to note that Gadamer was not interested in the epistemological question as much as the ontological position of the interpreter. For this reason, Gadamer begins and ends with the hypothetical, while Mead's scientific method includes initial prejudices but is not limited to it. As such, it would have better served Gadamer had he not adhered to a prejudice of methods generally understood, and instead narrowed his critique, in the spirit of pragmatism, to those methods of arriving at an understanding of our present experiences "entirely revealed" by an independent past (see Mead 2002). Nonetheless, Mead and Gadamer both arrived at the idea that our present prejudiced positions do not get in the way of understanding but are rather the conditions of possibility for it.

\section{Dilthey, Mead, and Gadamer. A Neglected Philosophical Tradition}

Recognizing this affinity between Gadamer and Mead, and their mutual criticism of Dilthey, ${ }^{12}$ I would like to turn now to the question, given the mutual influence Dilthey had on both thinkers, that this common ground between the two have yet to be highlighted by Mead scholars, particularly Hans Joas (see also Jung 1995).

It is only in his more recent essay titled "Pragmatism and Historicism: Mead's Philosophy of Temporality and the Logic of Historiography" that Joas begins to articulate an encounter between Mead's pragmatism and hermeneutics, broadly understood. I say "broadly understood" because Joas only uses the term hermeneutics once in a passing reference to Heidegger's hermeneutic circle, and only when describing how to deal with the most difficult passages of Mead's text (Joas 2016: 66). In this way, he only uses the term hermeneutics in its traditional textual interpretative sense of a methodology of the human sciences (Geisteswissenschaften). As a result, Joas again avoids any dialogue with Gadamer's philosophical hermeneutics. His reluctance to do so is likely due to the fact that Mead's The Philosophy of the Present primarily refers to the natural sciences whereas Gadamer's philosophical hermeneutics is motivated by a critique of the historicists' impulse to ground the human sciences in natural science's rigid methodologies (see Bernstein 1983). For Joas is right in emphasizing that "common to both [Mead and Dilthey] [...] was the intention of establishing a basis for objective knowledge and open-mindedness towards the natural sciences" (Joas 1997: 41). However, Joas himself admits that Mead's attempts to "naturalize" mental phenomena were constructed in non-reductionist forms. Alicia Garcia Ruiz (2013: 44) states this point more clearly in her essay on Mead, "The Concept of the Present and Historical Experience," when she stresses that the link between Mead and Dilthey is 
found in their shared aim to develop a historical method that emphasizes understanding as much as explanation. Unlike Dilthey, Mead's historical methods to interpreting the present focus on the possibility of infinite reconstructions. For Dilthey, historical knowledge can have a foundation, whereas for Mead, knowledge of the past is as hypothetical as the future (Mead, 2002: 44; see also Lee 1963). Viewed in this way, The Philosophy of the Present presents a damning critique of the philosophies of the natural and historical sciences of time. "We orient ourselves not with reference to the past which was a present within which the emergent appeared," Mead states, "but in such a restatement of the past as conditioning the future that we may control its reappearance." (Mead 2002: 46; emphasis added). Here, Mead's approach to historical knowledge looks more like an orientation to understanding the present than a specific method. Thus, Mead's philosophy of temporality, now reconsidered as a theory of understanding, is as much a critique of the natural sciences as they stand as it is a critique of historicism. Gadamer (2000), we know, provides the same critique of historicism. And as both Mead and Gadamer were heavily influenced by Dilthey, we may say, in the way that Gadamer (2007: 242) demands we trace each statement to the motivating question that precedes it, that both Mead and Gadamer were attempting to answer the questions left behind Dilthey's statements on the human sciences. That is, both thinkers were, to use Gadamer's words noted above, responding to the same challenge.

31 The current that runs through Dilthey, Mead, and Gadamer, then, is the notion that knowledge and truth can be revealed and realized through understanding. As noted above, it is important to emphasize that understanding, interpretation, and application are internally related (Gadamer 2006: 307; see also Bernstein 1983). This synthesis falls more in line with Mead's interpretation of the present as always including a practical orientation to the future funded by a reconstructed past than it does with Dilthey's methodological historicism.

To briefly demonstrate how highlighting the hermeneutic thread in Mead's later writings, and its affinities with Gadamer's philosophical hermeneutics, can inform not only each thinker's work, but the work of authors in either tradition, let us consider a criticism Joas (2016) gives of Mead in his essay "Pragmatism and Historicism."

Joas (2016) believes Mead to have failed to think of the moral universalism of roletaking in historical terms. As Mead's theory of role-taking plays a large part in his general theory of intersubjectivity, recognizing how the notion of intersubjectivity arrived historically can provide the answers that Joas so seeks from Mead. In Gadamer's (2000) late piece titled "Subjectivity and Intersubjectivity, Subject and Person," Gadamer gives a conceptual history of the account of intersubjectivity. In the article, Gadamer emphasizes the beginnings of the notion of subjectivity, and how the notion of persons, with its own conceptual tradition, dies out. Gadamer (2000: 285-6) sketches the conceptual origin of persons with its Greek expression in prosopon, meaning the "masks of actors, and hence also for the roles played by the actors in Attic theater," and continuing with the Latin, persona, and traces it all the way to Luther who "connected the concept of person most closely with that of fides, the rule of belief." Gadamer (2000) concludes the article by noting how history "remarkably" lost the philosophical conceptual language of persons to the modern concept of subjectivity, where if persons had remained a part of our philosophical discourse, it would more neatly align with our current theories of intersubjectivity. Perhaps, then, Joas could have benefited from 
having a conversation with Gadamer and the tradition of philosophical hermeneutics when developing his ideas not only in his book The Sacredness of the Person, but also his latest essay on Mead's historicism.

\section{Conclusion} history, Huebner $(2014,2016)$ neglects to identify the hermeneutic thrust of Mead's writings on history and the present. Huebner is not alone in his missed opportunity to explicitly identify the affinities between Mead's later writings and the hermeneutic tradition. As we noted, Joas $(1997,2016)$ too ignores any hermeneutic import to Mead as historicist, even when acknowledging the influence of Dilthey on the young Mead. Further still, the initiator of Mead's legacy within the sociological tradition, Herbert Blumer (1998), recognizes the importance of interpretation in the method of symbolic interactionism. But again, no mention is made of the relation between Mead's work and the hermeneutic tradition as it appears in Dilthey and Gadamer (Blumer 1998, 2004). Though pragmatist scholar Rosenthal (2000) emphasizes the importance of interpretation in Mead's philosophy of the present, she too misses an opportunity to reflect on the affinities between Mead's pragmatism and the hermeneutic tradition. These missed opportunities are likely due to the fact that the above interpreters of Mead, though even with their greatest efforts to do otherwise, read Mead from a rigidly historicist perspective instead of reading Mead the way Mead implored us to read our present situations (Mead 2002).

Both Mead and Gadamer would agree that "the real fulfillment of the historical task is to determine anew the significance of what is examined," recognizing, of course, that what is examined is always examined in a present complete with all of the prejudices we bring with its emergence (Gadamer 2006: 283). There is no doubt, however, that a more robust account of the affinities between pragmatism and philosophical hermeneutics must include a detailed discussion of Dilthey and Heidegger and to what extent language, the self, consciousness, sociality, perspectives and role-taking plays a part in Mead's hermeneutics. It would also serve our argument well if Gadamer's 
distinction of experience as Erlebnis and Erfahrung were explored in relation to Mead's analysis of continuity and novelty in the present. Moreover, a comparison between Mead's pragmatism and Gadamer's philosophical hermeneutics is incomplete without an inquiry into the important notion of play for both thinkers. And notwithstanding the arguments made above, certainly, there is value in recognizing the common ground between pragmatism and historicism. Nonetheless, Joas' (2016) particular account stops at Dilthey, and in turn, ignores Gadamer's philosophical hermeneutics. Rather than compare Dilthey's historicism to Mead's philosophy of time, I interpret Mead's philosophy of the present as an attempt to move beyond Dilthey's 'naive' historicist hermeneutics, and as such, Mead essentially provides a theory of applied interpretation of the present that simultaneously respects our traditions and prejudices while remaining open to future possibilities. As a result, Mead's philosophy of the present aligns more with Gadamer's philosophical hermeneutics than with methodological historicism.

\section{BIBLIOGRAPHY}

BERNSTEIN Richard J., (1983), Beyond Objectivism and Relativism: Science, Hermeneutics, and Praxis, Philadelphia, PA, University of Pennsylvania Press.

BERNSTEIN Richard J., (2010), The Pragmatic Turn, Malden, MA, Polity Press.

BLUMER Herbert, (1998), Symbolic Interactionism: Perspective and Method, Los Angeles, CA, University of California Press.

BLUMER Herbert, (2004), George Herbert Mead and Human Conduct, T. J. Morrione ed., Walnut Creek, CA, AltaMira Press.

BOLLNOW Otto Friedrich, (1936), Dilthey: Eine Einführung in seine Philosophie, Teubner, Leipzig.

BURKE Thomas F. \& Krzysztof Piotr SKOWRONSKI (eds), (2013), George Herbert Mead in the Twenty-First Century, Lanham, MD, Lexington Books.

CORRINGTON Robert S., (1995), The Community of Interpreters: On the Hermeneutics of Nature and the Bible in the American Philosophical Tradition, Macon, GA, Mercer University Press.

GADAMER Hans Georg, (2000), "Subjectivity and Intersubjectivity, Subject and Person," Continental Philosophy Review 33, 275-87.

GADAMER Hans Georg, (2006), Truth and Method, trans J. Weinsheimer \& D. G. Marshall, New York, NY, Continuum.

GADAMER Hans Georg, (2007), The Gadamer Reader: A Bouquet of The Later Writings, ed. R. E. Palmer, Evanston, IL, Northwestern University Press

GADAMER Hans Georg, (2008), Philosophical hermeneutics, ed. \& trans. D. E. Linge, Los Angeles, CA, University of California Press. 
GADAMER Hans Georg, (2019), Hermeneutics Between History and Philosophy: The Selected Writings of Hans-Georg Gadamer, Volume I, ed. \& trans. P. Vandevelde \& A. Iyer, New York, NY, Bloomsbury Publishing Plc.

GRONDIN Jean, (1994), Introduction to Philosophical Hermeneutics, trans. J. Weinsheimer, New Haven, CT, Yale University Press.

GRONDIN Jean, (2003), The Philosophy of Gadamer, trans. K. Plant, Ithaca, NY, McGill-Queen's University Press.

HoY David Couzens, (1982), The Critical Circle: Literature, History, and Philosophical Hermeneutics, Los Angeles, CA, University of California Press.

HUEBNER Daniel R., (2014), Becoming Mead: The Social Process of Academic Knowledge, Chicago, IL, University of Chicago Press.

HUEBNER Daniel R., (2016), “History and Social Progress: Reflections on Mead's Approach to History," European Journal of Pragmatism and American Philosophy, VIII, 2. Online: [journals.openedition.org/ejpap/637].

JOAS Hans, (1997), G. H. Mead: A Contemporary Re-Examination of His Thought, trans. R. Meyer, Cambridge, MA, MIT Press.

JOAS Hans, (2013), The Sacredness of the Person: A New Genealogy of Human Rights, Washington, DC, Georgetown University Press.

JOAS Hans, (2016), "Pragmatism and Historicism: Mead's Philosophy of Temporality and the Logic of Historiography," in Joas H. \& Huebner D. R. (eds), The Timeliness of George Herbert Mead, Chicago, IL, University of Chicago.

JOAS Hans \& Daniel R. HUEBNER (eds), (2016), The Timeliness of George Herbert Mead, Chicago, IL, University of Chicago.

JUNG Mathias, (1995), "From Dilthey to Mead and Heidegger: Systematic and Historical Relations," Journal of the History of Philosophy, 33 (4), 661-7.

LEE Harold N., (1963), “Mead's Doctrine of the Past," Tulane Studies in Philosophy 12, 52-75.

MEAD George Herbert, (1964), Selected Writings: George Herbert Mead, ed. A. J. Reck, Chicago, IL, University of Chicago Press.

MEAD George Herbert, (1972), The Philosophy of the Act, ed. C. W. Morris, Chicago, IL, University of Chicago Press.

MEAD George Herbert, (2002), The Philosophy of the Present, Amherst, NY, Prometheus Books.

MILLER David L., (1943), “G .H. Mead's Conception of 'Present'," Philosophy of Science, 10 (1), 40-6.

MILLER David L., (1973), George Herbert Mead: Self, Language, and the World, Chicago, IL, University of Chicago Press.

NATANSON Maurice, (1953), “George Herbert Mead's Metaphysics of Time,” Journal of Philosophy 50, 770-82.

TONNESS Alfred, (1932), “A Notion of the Problem of the Past - With Especial Reference to George Herbert Mead," The Journal of Philosophy, 29 (22), 599-606.

Rosenthal Sandra B., (2000), Time, Continuity, and Indeterminacy: A Pragmatic Engagement with Contemporary Perspectives, Albany, NY, SUNY Press. 
RUIZ Alicia Garcia, (2013), "The Concept of the Present and Historical Experience," in Burke T. F. \& Skowronski K. P. (eds), George Herbert Mead in the Twenty-First Century, Lanham, MD, Lexington Books.

WARNKE Georgia, (1987), Gadamer: Hermeneutics, Tradition and Reason, Stanford, CA, Stanford University Press.

\section{NOTES}

1. It is worth noting that Mead was also a student of Josiah Royce, the only pragmatist philosopher to develop a theory of interpretation. For more on Royce's theory of interpretation, I refer the reader to Corrington 1995.

2. In defining the emergent, Mead states: "A present then, as contrasted with the abstraction of mere passage, is not a piece cut out anywhere from the temporal dimension of uniformly passing reality. Its chief reference is to the emergent event, that is, to the occurrence of something which is more than the processes that have led up to it and which by its change, continuance, or disappearance, adds to later passages a content they would not otherwise have possessed." (Mead 2002: 52). Elsewhere Mead notes: "The emergent when it appears is always found to follow from the past, but before it appears it does not, by definition, follow from the past. It is idle to insist upon universal or eternal characters by which past events may be identified irrespective of any emergent." (Ibid.: 36). As such, all present experiences are reconstructive both as a result of and results in a "tang of novelty."

3. Gadamer scholar, Jean Grondin states, "all understanding," according to Gadamer, "is nothing other than an adjustment to the thing" (Grondin 2003: 86). That is, understanding is finding "accord" with the past in the present in order to "anticipate" the future (ibid.). For the similarities between this account of Gadamerian understanding and Mead's philosophy of the interpretation of the present as a process of adjustment I refer the reader to chapter 8 of Rosenthal (2000).

4. In "The Working Hypothesis in Social Reform" Mead makes a similar claim when he states: "A conception of a different world comes to us always as the result of some specific problem which involves readjustment of the world as it is, not to meet a detailed ideal of a perfect universe, but to obviate the present difficulty, and the test of this effort lies in the possibility of this readjustment fitting into the world as it is." (Mead 1964: 5).

5. Mead goes on to say, "Is there a similar error in the conception of correction of the past error and in the suggestion that it implies the absolutely correct, even if it never reaches it? I am referring to the 'in-itself' correctness of an account of events, implied in a correctness which lies back in the historian's mind would be found to be in the complete presentation of the given past, if all its implications were worked out." (Mead 2002: 40-1). This is the same "romantic" error of original intention Gadamer subscribes to Schleiermacher.

6. Mead states, "The specious present is the immediate field conditioning possible action" (Mead 1972: 228).

7. Though Miller (1973: 172) references the quote, he says nothing of its hermeneutic import.

8. We may also note that much like the notion of "what we have," Mead's use of the phrase "common background of thinking" sounds much like Gadamer's Heideggerian use of the notion "foregrounding" as both asserting and questioning one's prejudices, and in turn, tradition.

9. With the exception of his essay "The Universality of the Hermeneutic Problem" and "On the Circle of Understanding," after Truth and Method Gadamer hardly ever made use of the notion of prejudice again (Grondin 2003: 90). It is likely that due to how intrenched the negative connotations of prejudice are to modern ears, Gadamer thought his attempt to rehabilitate the 
original use of prejudice led to more misunderstanding than elucidation of the main purpose for enlisting the notion - the inescapability, even for the methodological scientist, of historical situatedness.

10. It is important to note that, for Mead, when referring to a hypothesis it is not merely the initial attitude of the scientist in the laboratory, but also to the conduct of any individual, who by acknowledging their hypotheses as hypotheses in a historicallyeffected way becomes scientifically oriented (Mead 1964: 3). In relation to this point, Mead refers to the "logical analysis of the experimental method" as "merely the elaboration of the simple processes of everyday inference by which we meet our constantly recurring difficulties" (Mead 1972: 82-3).

11. Compare this to Gadamer's note on the relationship between hermeneutics and science: "Hermeneutics also has relevance to the theory of science in that hermeneutic reflection discloses conditions of truth in the sciences that do not derive from the logic of scientific discovery but are prior to it." (Gadamer 2006: 556).

12. It is my belief that Mead's later writings are in constant dialogue with Dilthey. It is, however, out of the purview of this study to properly argue the point here. It will be enough to point out Dilthey's general influence on Mead.

13. Huebner's historical analysis unearths the following: "In several cases, Morris's notes to himself indicate that he asked students to transcribe their notes or otherwise rewrite them into a more complete form. That is, not only were the contents of the potential volumes constructed in the sense of selected from among the possible notes, but there was also a literal construction of the materials themselves for the volumes." (Huebner 2014: 121). Aside from the liberties taken by Morris when summarizing and paraphrasing the students' lecture notes from Mead's courses, Huebner goes on to say, "in asking students to rewrite their notes [Morris] in effect asked them to build a whole new layer of interpretation into the materials he would then receive, a layer that would be indistinguishable to Morris from the notes as written in the classroom" (ibid.: 122).

\section{ABSTRACTS}

In this article I draw together what is a largely neglected account of the hermeneutic thrust of Mead's late writings. In particular, I argue that Mead's philosophy of the present also amounts to a theory of interpretation. In an open dialogue with a number of Hans-Georg Gadamer's most fundamental concepts, I demonstrate how Mead's notion of emergence in the present of both past and future neatly aligns with Gadamer's philosophical hermeneutics. I will trace the foundation of this common ground by highlighting the pivotal influence of Wilhelm Dilthey on both Gadamer and the young Mead. Then, I will draw out the consequences this mutual influence has on the critique of the methodological historicist tradition. Throughout I demonstrate several missed opportunities by Hans Joas at providing a philosophical hermeneutic account of Mead's work. It is my intention to display how together the traditions of philosophical hermeneutics and pragmatism inform one another. 
AUTHOR

SCOTT C. TAYLOR

New Jersey City University

staylor2[at]njcu.edu 